\title{
Sistem Informasi Geografis Objek Wisata Alam di Provinsi Sumatera Utara Berbasis Mobile Android
}

\section{Geographic Information System Object of Natural Tourism in North Sumatra Province Based Mobile Android}

\author{
Helmi Kurniawan ${ }^{1}$, Muhammad Rusdi Tanjung ${ }^{2}$ \\ 1,2Universitas Potensi Utama; Jl. K.L. Yos Sudarso KM 6,5 No. 3A Tanjung Mulia Medan \\ ${ }^{1,2}$ Program Studi Teknik Informatika, FTIK Universitas Potensi Utama, Medan \\ $\underline{1}$ Helmikurniawan77@gmail.com,$\stackrel{2}{2} \underline{\text { rsd.adi@gmail.com }}$
}

\begin{abstract}
Abstrak
Provinsi Sumatera Utara merupakan propinsi yang sangat di kenal karena memiliki daerah wisata yang banyak pada setiap kabupaten bahkan sampai kecamatan yang ada di Sumatera Utara. Sistem informasi yang menyajikan informasi daerah-daerah wisata Sumatera Utara telah banyak dibuat. Namun hanya menampilkan gambar dan namanya saja yang disajikan dalam bentuk peta, media iklan surat kabar dan web yang belum menyajikan petunjuk langsung ke lokasi wisata yang dituju. Permasalahan yang didapat dari informasi media tersebut bagi wisatawan adalah tidak mendapatkan pentunjuk langsung lokasi wisata letak posisi secara geografisnya. Hal ini dibutuhkan teknologi yang dapat menyajikan infromasi objek wisata yaitu Sistem informasi geografis (SIG) Seperti hal dengan informasi yang memberi penjelasan dalam informasi wisata harus meliputi data dan gambar yang nyata dan benar. Sehingga para wisatawan yang ingin bepergian ke Propinsi Sumatera Utara tetapi masih belum tahu lokasi atau tempat objek wisata yang menarik untuk dikunjungi dapat mengetahuinya. Untuk mengatasi masalah tersebut penulis menggunakan pendekatan pada model pemetaan digital berupa SIG dengan berbasis mobile android memanfaatkan google maps sebagai peta digital. Metode yang di pakai dalam peneltian ini dengan menggunakan UML (Unifed Modeling Language), program PHP, java dan database MySQL sebagai penyimpanan data. Sistem informasi Geografis (SIG) objek wisata alam ini memiliki dua program yaitu program admin untuk mengelola data wisata berbasis web dan program user untuk menampilkan objek wisata berbasis mobile android. Sistem informasi geografis ini bertujuan untuk memberikan kemudahan dan kecepatan kepada masyarakat dalam memperoleh informasi mengenai Objek Wisata Alam di Propinsi Sumatera Utara.
\end{abstract}

Kata kunci-System Information Geografis, Wisata Alam, Android, Google Maps

\begin{abstract}
North Sumatra Province is a province that is so known because it has many tourist areas in each district to district and even in North Sumatra. The information system that provides information tourist areas of North Sumatra have been produced. But just to show a picture and the name alone that is presented in the form of maps, newspaper advertising media and web yet provides instructions directly to the location of the intended travel. The problems that come from the media information for tourists are not getting direct instructions of tourist sites in the geographic location of the position. It is a need for technology that can present Attraction infromasi ie geographic information system (GIS) Such is the case with information explaining the travel information should include data and images are real and true. So that the tourists who want to travel to North Sumatra province but still do not know the location or point
\end{abstract}


of attractions of interest to visit can know. To overcome these problems the author uses digital mapping approaches in model form android based mobile GIS with google maps utilizing a digital map. The method in use in this research by using UML (Unifed Modeling Language), the program PHP, Java and MySQL database for data storage. Geographic information systems (GIS) natural attractions has two programs, namely the program administrators to manage data and web-based travel program to show the user attraction android based mobile. Geographic information system aims to provide convenience and speed to the public in obtaining information about attractions Nature in North Sumatra Province

Keywords - Geographic Information System, Natural Tourism, Android, Google Maps

\section{PENDAHULUAN}

Indonesia dikenal sebagai Negara agraris hendaknya memajukan daerah-derah wisata yang ada untuk di gunakan sebagai penambah devisa negara, khusunya Sumatera Utara yang terdapat begitu banyak tempat-tmpat wisata yang harus di kembangkan. Provinsi Sumatera Utara terletak pada $1^{\circ}-4^{\circ}$ Lintang Utara dan $98^{\circ}-100^{\circ}$ Bujur Timur, Luas daratan Provinsi Sumatera Utara $72.981,23 \mathrm{~km}^{2}$.

Provinsi Sumatera Utara merupakan propinsi yang sangat di kenal karena memiliki daerah wisata yang banyak pada setiap kabupaten bahkan sampai kecamatan yang ada di Sumatera Utara. Sumatera utara yang merupakan daerah yang memiliki objek wisata yang terkenal sampai dunia yaitu danau toba ternyata juga memiliki tempat wisata lainnya yang belum dapat diinformasikan. Kebanyakan Wisatawan tidak mengetahui letak dari objek wisata yang dikunjungi secara geografis. Untuk mengetahui objek wisata yang ada wisatwan masih banyak yang menggunakan peta. Dengan menggunakan peta, pengguna dapat mengetahui letak objek wisata tersebut bukan hanya namanya saja, tetapi daerah-daerah sekitar bahkan kecamatan dan kabupaten bisa diketahui melalui peta yang ditampilkan. Dengan menggunakan peta, setiap objek wisata bisa dicantumkan berdasarkan kabupaten ataupun kecamatan.

Namun dengan banyaknya informasi penyajian pun harus disesuaikan dengan objeknya. Untuk itu dibutuhkan informasi yang tepat dan akurat untuk menyebarluaskan informasi tersebut. Penyebaran informasi geografis ini dapat berupa data spasial (wilayah) maupun data non spasial berupa informasi yang berhubungan dengan keberadaan wilayah. Penyebaran informasi pada bidang geografis juga bermanfaat di bidang Objek Wisata alam yang menggunakan informasi pemetaan (geografis) untuk menyebarkan secara rinci dimana setiap kota maupun daerah itu mempunyai objek Wisata yang dapat dikunjungi oleh para wisatawan. Untuk itu dipertulakn sistem informasi yang dapat menyajikan informasi objek wisata di propinsi Sumatera Utara.

Sistem Informasi Geografis (SIG) dapat diterapkan untuk mengatasi masalah tersebut. Sistem informasi Geografis (SIG) mempunyai kemampuan menyimpan data dan memanipulasi informasi berdasarkan data geografis. Hal inilah yang membedakan Sistem Informasi Geografis (SIG) dengan system informasi lainnya. Teknologi GIS (Geographic Information System) mengalami perkembangan yang sangat pesat. Diantaranya adalah Mobile GIS dimana GIS yang tadinya hanya digunakan di dalam lingkungan kantor menjadi semakin fleksibel dan mampu digunakan di luar kantor secara mobile. Mobile GIS dapat digunakan untuk menangkap, menyimpan, update, manipulasi, analisa dan menampilkan informasi geografi secara mudah [1][2][3].

Sistem Informasi Geografis yang akan dikembangkan dalam penyampaian informasi dapat digunakan melalui telepon seluler yang saat ini semakin berkembang dan mempermudah masyarakat melalui sistem operasinya. Salah satu sistem operasi terbaru saat ini adalah sistem operasi android. Sistem Android memungkinkan developer membangun aplikasi sendiri dengan menggunakan bahasa pemrograman Java. Sistem Informasi Geografis berbasis Android dapat menjadi salah satu alat bantu utama yang mobile interaktif. Data spasial yang menunjukkan 
letak lokasi fasilitas umum pada kondisi sesungguhnya ditampilkan pada handphone seluler (Android) yang dibawa[4][6]. Teknologi Android dalam sistem informasi geografis ini mempunyai banyak keunggulan diantaranya: memungkinkan mobilitas/pergerakan dari user, free/gratis, mudah untuk dibangun/easy to development, multitasking [5]. Perlunya sistem informasi objek wisata berbasis mobile di Sumatera Utara bertujuan untuk memberikan informasi objek wisata kepada wisatawan dan diharapkan supaya wisata-wisata yang ada didaerah semakin dikembangkan hingga akhirnya semakin di kenal oleh seluruh lapisan masyarakat di Indonesia bahkan dunia.

\section{METODE PENELITIAN}

\subsection{Metode}

Metode penelitian yang dilakukan dalam perancangan sistem informasi geografis objek wisata alam Sumatera Utara melalui beberapa tahapan yang akan dilaksanakan untuk mencapai hasil yang ditargetkan yaitu Sistem Informasi Geografis Wisata Alam berbasis Mobile Android. Tahapan-tahapan metode penelitian sistem informasi geografis wisata alam adalah:

1. Tahap perencanaan sistem, yang dilakukan disini adalah mendefinisikan permasalahan yang terjadi, Masalah yang dihadapi Informasi lokasi objek wisata alam Sumatera Utara adalah tidak adanya sistem yang mendukung tentang informasi pariwisata serta menunjukan lokasi-lokasi tujuan wisata, mengingat objek pariwisata dikabupaten dan kecamatan banyak belum diketahui, maka perlu dibangun suatu sistem yang dapat membantu pengelolaan lokasi dan informasi pariwisata, sehingga dapat mempermudah pencarian informasi, promosi dan pengelolaan data kepariwisataan Sumatera Utara.

2. Tahap Analisa, tahap ini dilakukan dengan menganalisa sistem yang telah berjalan, yaitu promosi obyek wisata yang ada pada saat ini masih menggunakan metode konvensional, yaitu dengan cara promosi melalui media cetak maupun pamphlet serta belum tersedianya sistem aplikasi berbasis mobile yang memberikan informasi wisata alam dan untuk pengelolaan obyek wisata alam di Sumatera Utara.

3. Tahap perancangan sistem, kegiatan yang dilakukan yaitu membuat pemodelan proses dengan menggunakan UML, pemodelan data survey yang diolah dan disimpan dalam database MySQL untuk dapat ditampilkan pada Peta Digitasi yang memanfaatkan google Maps, dan membuat desain tampilan antar muka (interface) menggunakan PHP untuk program web admin dan java untuk program user mobile android.

4. Tahap Implementasi sistem, Perangkat keras yang diperlukan untuk mengembangkan Sistem Informasi geografis adalah sebuah komputer dengan spesifikasi Processor Intel Core i3, memory $2 \mathrm{~GB}$, hardisk minimal $500 \mathrm{Mb}$, perangkat mobile android (android versi 2.3 keatas) yang mendukung GPS (Global Positioning System). Perangkat lunak yang digunakan adalah sistem operasi Windows 7, Xampp, Notepad++, EMS SQL Manager, Google Chrome, Eclipse. Metode Pengujian yang digunakan adalah pengujian kotak hitam (black box testing) yaitu dengan cara memberi input dari pengguna kepada sistem yang sudah berjalan dan mengamati hasil output dari system.

\subsection{Analisis Data}

Berdasarkan data yang telah diperoleh, maka pembahasan penelitian ini digunakan alur analisis yang disusun dengan langkah-langkah berbentuk diagram alir seperti di bawah ini: 


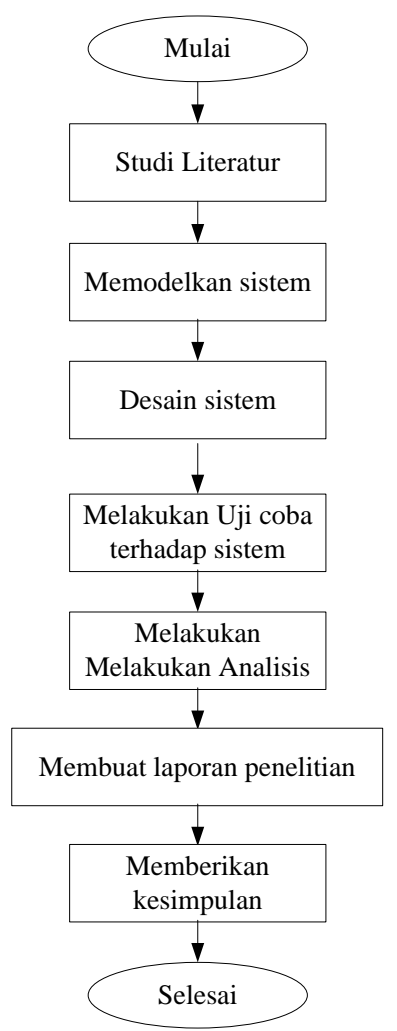

Gambar 1. Alur Analisis.

\section{HASIL DAN PEMBAHASAN}

Sistem informasi objek wisata yang di tampilkan oleh kebanyakan website sekarang hanyalah menampilkan gambar dan keterangan bagi pengunjung website tersebut. Dalam hal ini penulis mengamati masalah yang ada, yaitu bahwa setiap pengunjung website pariwisata hanya mengetahui objek wisata berupa gambar dan teks yang merupakan keterangan ataupun informasi dari gambar tersebut, tanpa tahu dimana letak dari objek wisata tersebut.

Kebanyakan orang-orang tidak mengetahui letak dari objek wisata yang dikunjungi secara geografis. Dengan menggunakan peta pengguna dapat mengetahui letak objek wisata tersebut bukan hanya namanya saja, tetapi daerah-daerah sekitar bahkan kecamatan dan kabupaten bisa diketahui melalui peta yang ditampilkan pada website wisata. Dengan menggunakan peta, setiap objek wisata bisa dicantumkan berdasarkan kabupaten ataupun kecamatan.

Dalam hal ini, penulis menggunakan peta untuk menunjukkan dareah wisata yang akan dijalani. Dimana didalam peta akan di desain objek wisata kabupaten yang dirancang untuk menampilkan objek wisata berdasarkan daerah-daerah yang ada di kabupaten. Peta yang didesain merupakan peta dari setiap kabupaten dapat diakses melalui google map berbasis android.

Adapun data-data dari objek wsiata yang akan di inputkan kedalam sistem adalah sebagai berikut:

1. Data Objek Wisata Kabupaten Karo

Pada tabel berikut ini ada beberapa objek wisata yang ada di kabupaten Karo, tetapi tidaklah semua karena masih ada yang belum di kenal olesh masyarakat. Adapun objek-objek yang akan di tampilkan adalah sebagai berikut: 
Tabel 1. Objek Wisata Kabupaten Karo

\begin{tabular}{rlll}
\hline No & \multicolumn{1}{c}{ Objek Wisata } & \multicolumn{1}{c}{ Jenis Wisata } & Kabupaten \\
\hline 1 & Gundaling & Bukit & Karo \\
\hline 2 & Sipiso-piso & Air Terjun & Karo \\
\hline 3 & Gunung Berapi Sibayak & Alam & Karo \\
\hline 4 & Tongging & Pemandangan dan Pantai & Karo \\
\hline 5 & Lau Debuk-debuk & Pemandian Air Panas & Karo \\
\hline 6 & Danau Law Kawar & Danau & Karo \\
\hline 7 & Gua Lang Dahar & Gua & Karo \\
\hline 8 & Sikulikap & Air Terjun & Karo \\
\hline 9 & Desa Lingga & Rumah Tradisional & Karo \\
\hline 10 & Taman Hutan Raya Bukit & Alam & Karo \\
& Barisan & & \\
\hline
\end{tabular}

2. Datal Objek Wisata Kabupaten Simalungun

Berikut ini objek wisata yang akan ditampilkan dari kabupaten Simalungun, namun belum seluruhnya. Adapun objek-objek yang akan di tampilkan adalah sebagai berikut:

Tabel 2. Objek Wisata Kabupaten Simalungun

\begin{tabular}{rlll}
\hline No & \multicolumn{1}{c}{ Objek Wisata } & & Jenis Wisata \\
\hline 1 & Parapat Danau Toba & Danau & Simalungun \\
\hline 2 & Simarjunjung & Pemandangan & Simalungun \\
\hline 3 & Tinggi Raja & Alam & Simalungun \\
\hline 4 & Simarjunjung & Perkebunan teeh & Simalungun \\
\hline 5 & Tigaras & Pantai & Simalungun \\
\hline 6 & Haranggaol & Pantai dan Pemandangan & Simalungun \\
\hline 7 & Kebun Binatang & Alam & Pematang Siantar \\
\hline
\end{tabular}

3. Data Objek wisata Kabupaten Medan

Medan merupukan kota metropolitan kedua yang ada di Indonesia. Dimana kebanyakan penduduknya merupakan suku Batak.

Tabel 3. Objek Wisata Kota Medan

\begin{tabular}{llll}
\hline No & Objek Wisata & Jenis Wisata & Kabupaten \\
\hline 1 & Pantai Bali Lestari & Pantai & Medan \\
\hline 2 & Danau Siombak & Danau & Medan \\
\hline 3 & Armaya Wisata Alam & Alam & Medan \\
\hline 4 & Danau Linting & Danau & Medan \\
\hline 5 & Air Terjun Pelaruga & Air Terjun & Medan \\
\hline 6 & Wisata Batu Katak & Alam & Bahorok \\
\hline 7 & Bukit Lawang & Bukit & Bahorok \\
\hline
\end{tabular}

4. Data Objek Wisata Sibolga

Berikut ini merupakan objek-objek wisata yang sering dikunjungi di Sibolga, dimana Sibolga juga kaya akan hasil lautnya.

Tabel 4. Objek Wisata Kabupaten Sibolga

\begin{tabular}{|c|c|c|c|}
\hline No & Objek Wisata & Jenis Wisata & Kabupaten \\
\hline 1 & Sibolga & Pantai & Sibolga \\
\hline 2 & Bukit Katepang & Alam & Sibolga \\
\hline 3 & Gua Sikaje-kaje & Goa & Sibolga \\
\hline 4 & Gua Tangga Seratus & Goa & Sibolga \\
\hline 5 & Benteng Sihipo-hipo & Sejarah & Sibolga \\
\hline
\end{tabular}


Sistem Informasi Geografis Objek Wisata Alam ...

\begin{tabular}{rlcl}
\hline 6 & Pulau Poncan Gadang & Pulau & Sibolga \\
\hline 7 & Pulau Panjang & Pulau & Sibolga \\
\hline 8 & Pulau Sarudik & Pulau & Sibolga \\
\hline 9 & Torsimarbarimbing & Gunung & Sibolga \\
\hline 10 & Poncan Ketek & Pulau & Sibolga \\
\hline 11 & Pantai Ketapang & Pantai & Sibolga \\
\hline
\end{tabular}

5. Data Objek Wisata Kabupaten Tapanuli Selatan

Tapanuli Selatan juga memiliki objek-objek wisata yang tak kalah menarik. Berikut objekobjek wisata yang dapat dikunjungi oleh wisatawan.

Tabel 5. Objek Wisata Kabupaten Tapanuli Selatan

\begin{tabular}{cllc}
\hline No & Objek Wisata & Jenis Wisata & Kabupaten \\
\hline 1 & Portibi & Candi & Tapanuli Selatan \\
\hline 2 & Sipirok & Air Panas & Tapanuli Selatan \\
\hline 3 & Aek Sijornih & Pemandian & Tapanuli Selatan \\
\hline 4 & Danau Siais & Danau & Tapanuli Selatan \\
\hline 5 & Sopo Godang & Rumah Tradisional & Tapanuli Selatan \\
\hline
\end{tabular}

6. Data Objek Wisata Kabupaten Toba Samosir

Berikut objek-objek wisata yang sering dikunjungi oleh masyarakat sekitar, bahkan dari luar daerah.

Tabel 6. Objek Wisata Toba Samosir

\begin{tabular}{rlcl}
\hline No & \multicolumn{1}{c}{ Objek Wisata } & Jenis Wisata & Kabupaten \\
\hline 1 & Taman Eden 100 & Alam & Toba Samosir \\
\hline 2 & Lumban Silintong & Pantai & Toba Samosir \\
\hline 3 & Mual Sirambe & Pantai & Toba Samosir \\
\hline 4 & Pohon Hariharangga & Sejarah & Toba Samosir \\
\hline 5 & Lumban Binanga & Danau & Toba Samosir \\
\hline 6 & Sibaruang & Desa & Toba Samosir \\
\hline 7 & Goa Sipege & Goa & Toba Samosir \\
\hline
\end{tabular}

\subsection{Perancangan}

Perancangan sistem informasi geografis objek wisata alam di Sumatera Utara dibangun oleh dua sisi program yang terdiri dari program server admin dan program clien user. Program Server admin terdiri dari webservice, database Mysql sedangkan dari program client user terdiri dari aplikasi mobile GIS. Data survey yang terkait dengan data atribut diolah dan dimasukkan ke dalam database dengan menggunakan Mysql.Data hasil dari digitasi pada mapinfo dengan format *.tab dikonversi ke format *.shp menggunakan universal translator. Kemudian diproses oleh shapefile and dbf loader/exsporter file untuk masuk ke dalam database.

Satelit GPS berguna untuk memberikan koordinat pengguna sehingga dapat ditampilkan pada peta google maps. Pada proses perancangan yang akan dilakukan penulis akan melakukan perancangan dimana nanti aplikasi dapat ter-install pada perangkat android sebagai media informasi wisata alam Sumatera Utara yang akan menunjukkan ke tempat lokasi wisata yang dituju. Syarat utama dari aplikasi ini dapat berjalan dengan baik ialah aktifnya koneksi data internet yang telah disediakan, selain itu juga harus aktifnya fungsi dari GPS. GPS dalam hal ini adalah berfungsi untuk menentukan titik-titik koordinat dari keberadaan perangkat yang lokasi tempat yang dituju, dan kemudian hasil dari marking point yang diperoleh akan dikirimkan kepada user yang kemudian akan diterjemahkan kedalam peta google, sehingga lokasi dari tempat yang dituju tersebut dapat langsung terlihat pada peta dan mendapatkan informasi nama lokasi wisata alam yang dituju. Sistem informasi geografis wisata alam 
sumatera utara dibuat oleh penyusun dalam bentuk notasi Unified Modelling Language (UML) ini mewakili secara sederhana dan bisa dijadikan sebagai bahan dalam perancangan secara efektif, sehingga sistem dapat terlihat tanpa harus mengetahui secara detail. Perancangan sistem informasi objek wisata dimodelkan dengan menggunakan UML (Unifed Modeling Language), penggambaran UML dapat dilihat seperti gambar berikut ini :

\subsubsection{Use Case Diagram}

Pada perancangan sistem ini menggunakan use case diagram agar lebih mudah megatahui jalannya proses ini dan gambaran dari perancangan sistem ini. Berikut perancangan use case diagram yang di bentuk.

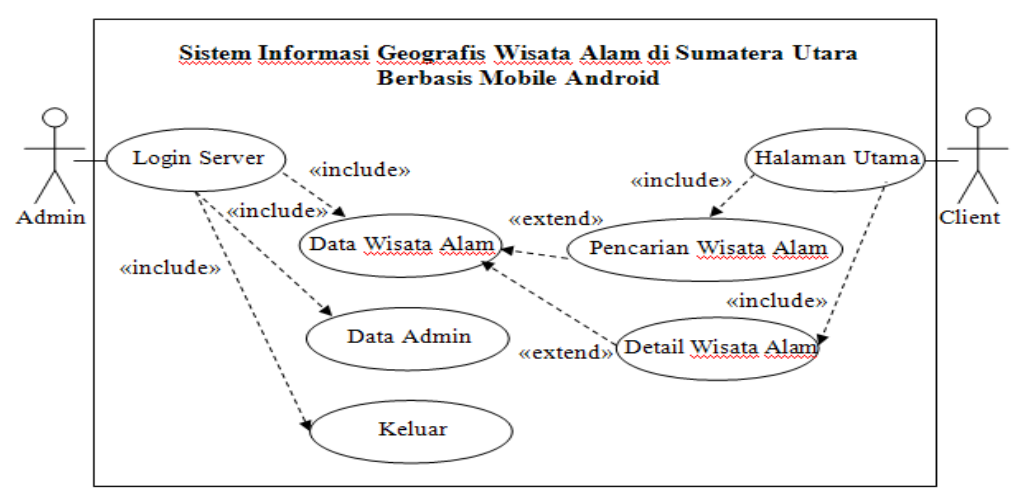

Gambar 2. Diagram Use Case Admin dan Client

Pada perancangan use case admin disini, hanya admin yang diperbolehkan untuk masul (login) di admin. Dikarenakan untuk menjaga keamanan dari web tersebut. Dan hanya admin yang boleh mengedit dan merubah data apabila terjadi perubahan, sehingga informasi yang diperoleh selalu update.

\subsubsection{Diagram Sequence Manage Data Di Server}

Pada tahapan perancangan ini diagram sequence digunakan untuk menjelaskan sistem yang berjalan yaitu, admin menginputkan data wisata yang kemudian disimpan ke database yang akan memberikan informasi dan akan memberikan informasi tersebut ke user.

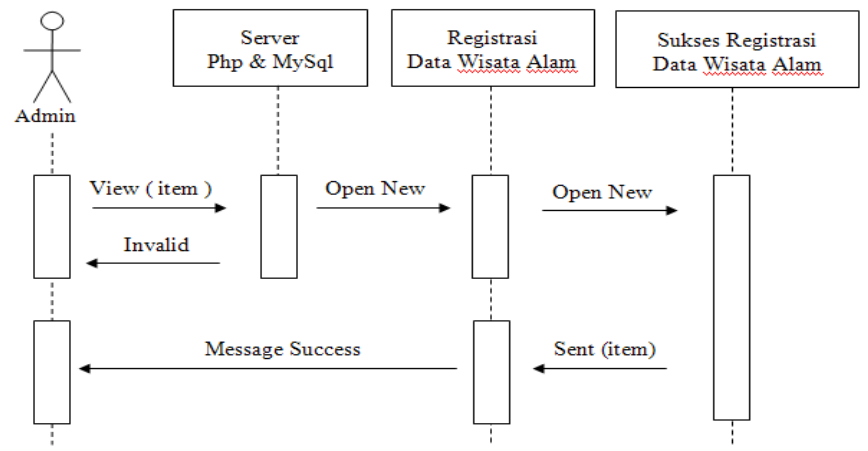

\section{Gambar 4. Sequence Diagram Manage DataWisata Alam di Server}

\subsubsection{Diagram Sequence Wisata Alam Untuk User Mobile}

Diagram sequence yang terlihat pada gambar 5 menjelaskan tampilan data Wisata Alam Sumatera Utara yang telah diinputkan oleh admin melalui web dan kemudian ditampilkan dalam 
bentuk informasi data wisata alam di mobile android oleh user, dimana user dapat melihat objek wisata alam dan mencari wisata alam yang diinginkan pada aplikasi wisata alam berbasis mobile.

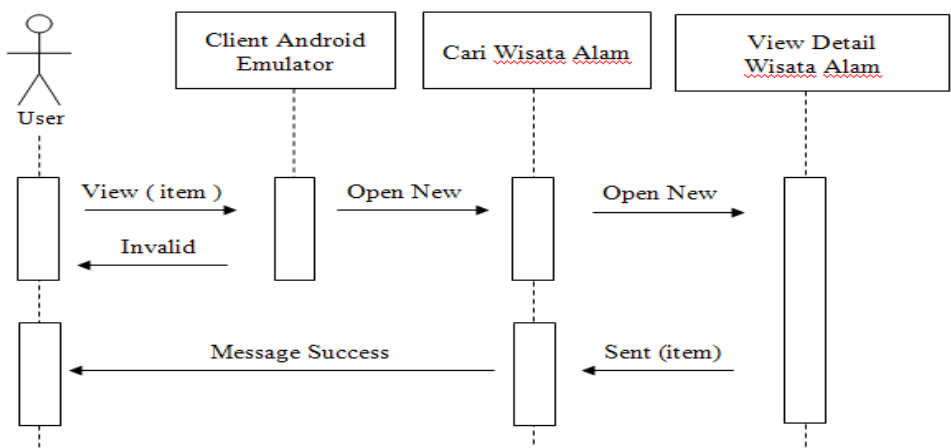

Gambar 5. Diagram Sequence Penginputan Data Kategori

\subsubsection{Diagram Sequence Titik Koordinat}

Diagram ini menjelaskan penginputan data titik koordinat yang kemudian diinputkan dengan membuka form titik koordinat kemudian data tersebut disimpan ke database yang kemudian ditampilkan dalam bentuk informasi. Objek wisata juga akan diinputkan melalui penginputan data melalui form titik koordinat oleh admin. Dengan demikian diagram sequence sangat membantu penulis untuk merancang sebuah sistem yang dapat berguna.

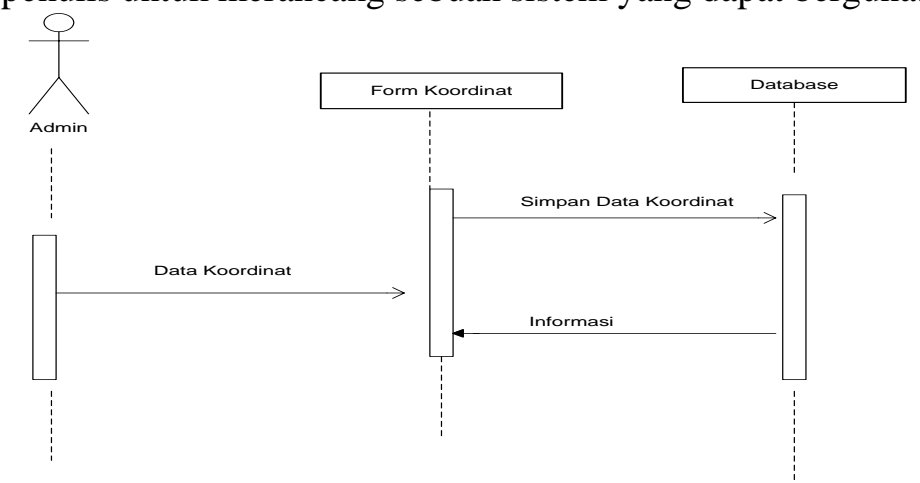

Gambar 6. Diagram Sequence Penginputan Titik Koordinat

\subsubsection{Desain Database}

Database pemesanan ini berfungsi sebagai tempat penyimpanan data-data pemesanan yang telah dilakukan sehingga mempermudah dalam pembuatan laporan yang akan diberikan kepada admin dan pengguna. Database dan tabel dapat dilihat pada gambar 7. berikut ini.

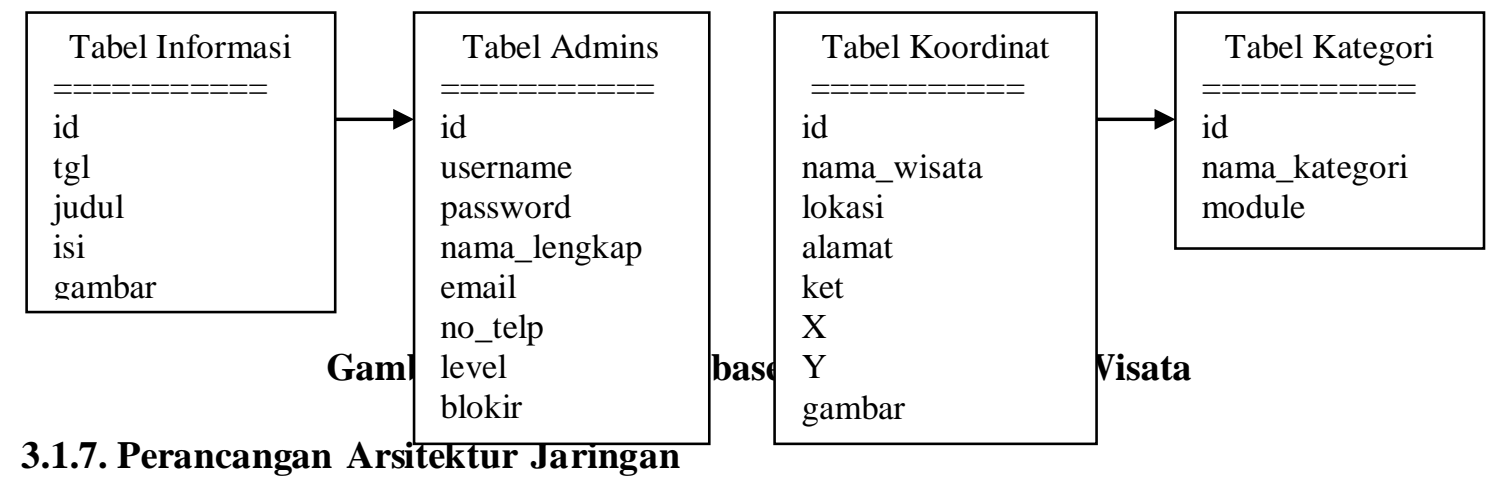

Perancangan sistem informasi geografis objek wisata alam di Sumatera Utara dibangun oleh dua sisi program yang terdiri dari program server admin dan program clien 
user. Program Server admin terdiri dari webservice, database Mysql sedangkan dari program client user terdiri dari aplikasi mobile GIS. Location based service ketika pertama dibuka langsung akan mencari tahu lokasi pengguna saat ini Setelah Lokasi diketahui maka melalui internet sistem akan melakukan request ke Google Maps sebagai penyedia API. Request yang dilakukan berupa request peta berdasarkan lokasi user saat ini, dan ketika request itu berhasil diterima, maka Google Maps akan segera merespon aplikasi dengan memberikan akses peta kepada aplikasi. Selain itu Ketika lokasi berhasil diketahui, maka melalui internenet juga aplikasi akan melakukan request ke web service. Web Service yang dibangun berguna untuk mengambil data pada database, request dari aplikasi tadi diubah menjadi query oleh web service.

Ketika Database yang berbentuk SQL ini berhasil menerima lalu memproses query, maka database akan memberikan data SQL sesuai dengan yang diminta oleh Web Service. Proses dari fungsional sistem dikelola oleh webservices dengan data dalam format JSON. Kemudian data diubah menggunakan JSONparser agar dapat disajikan kepada pengguna. Arsitektur Sistem Informasi Geografis Objek Wisata alam Sumatera Utara ini dapat pada gambar 8 .

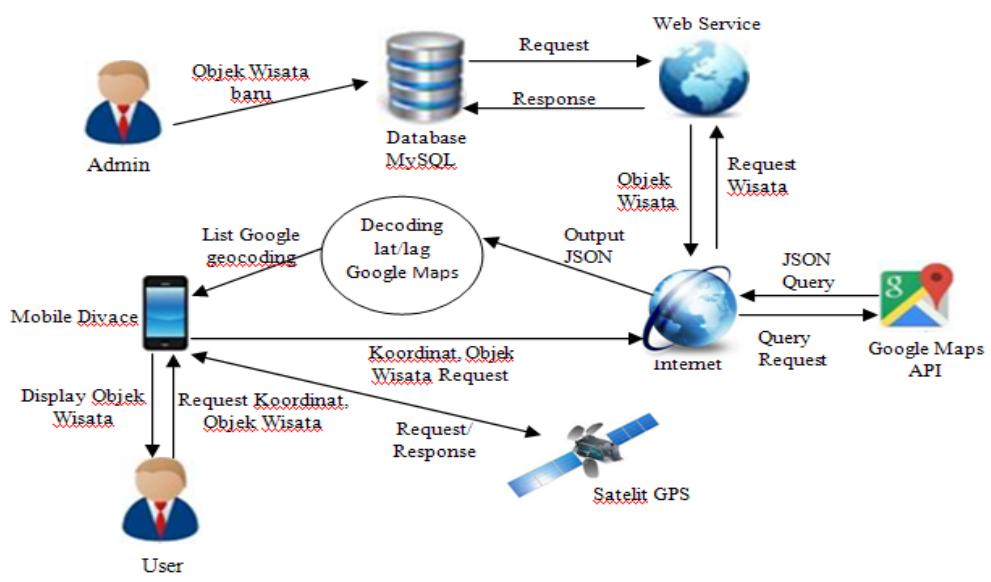

Gambar 8.Perancangan Arsitektur SIG Objek Wisata Alam

\subsection{Pembahasan}

Dari sistem yang dirancang penulis dapat melakukan perancangan objek wisata ini menggunakan peta dari setiap kabupaten yang telah diunjuk dan ditentukan pada batasan masalah. Yaitu, user bisa mengunjungi web kapan saja dengan membuka website pariwisata. Kemudian user bisa menentukan wisata dengan melihat kabupaten-kabupaten yang ditampilkan yang pada tab-tab. Dan didalam kabupaten itu terdapat peta kabupaten yang di beri titik untuk menunjukkan objek wisata, apabila titik tersebut di klik maka akan muncul objek wisata yang di inginkan yaitu gambar beserta keterangan dari objek wisata tersebut.

Adapun admin yang ditampilkan pada tampilan menu home, berfungsi untuk mengedit data yaitu menghapus dan menambah data objek wisata serta mengganti data berita. Dengan demikian hanya admin yang bisa masuk ke admin utnuk merubah dan menambah data. Berikut ini adalah tampilan hasil dari program yang dirancang. Tampilan ini adalah tampilan awal dari pada program. Berikut ini adalah hasil tampilan menu home pada aplikasi wisata alam.

\subsubsection{Hasil}


Tampilan hasil adalah tampilan yang berisikan beberapa halaman terdapat didalam aplikasi, tampilan layar terdiri dari beberapa halaman seperti halaman utama, Halaman Penentuan lokasi, dan Halaman Peta.

Pada icon WisataAlam.apk untuk diinstall di Handphone android dan selanjutnya pengguna dapat menggunakan aplikasi. Berikut ini adalah tampilan gambar aplikasi peta yang telah di instal di hanphone android.

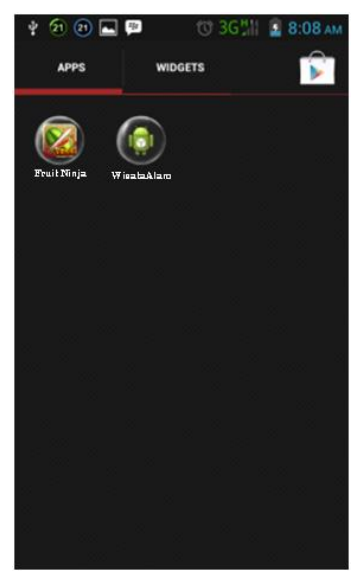

\section{Gambar 9. Tampilan Aplikasi WisataAlam di Android}

\subsubsection{Tampilan Aplikasi Wisata Alam}

Tampilan awal aplikasi peta adalah tampilan pertama kali pengguna menjalankan aplikasi di Android. Pada tampilan awal user akan melihat Wisata Alam Sumatera Utara yang terdapat beberapa gambar wisita yang ditujukan ke tempat lokasi tertentu. Berikut ini adalah tampilan awal dari aplikasi Wisata Alam yang tampil pada android.

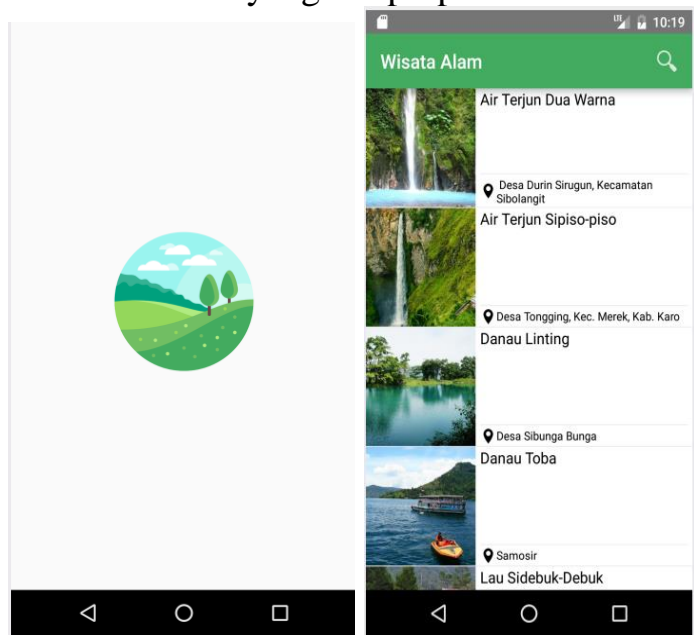

Gambar 10. Tampilan Utama Aplikasi Wisata Alam

Tampilan peta adalah tampilan mennjukkan peta lokasi wisata alam kepada pengguna menjalankan aplikasi di Android. Pada tampilan user akan melihat Wisata Alam Sumatera Utara yang terdapat beberapa marker yang ditujukan ke tempat lokasi tertentu. Berikut ini adalah tampilan peta dari aplikasi Wisata Alam yang tampil pada android 


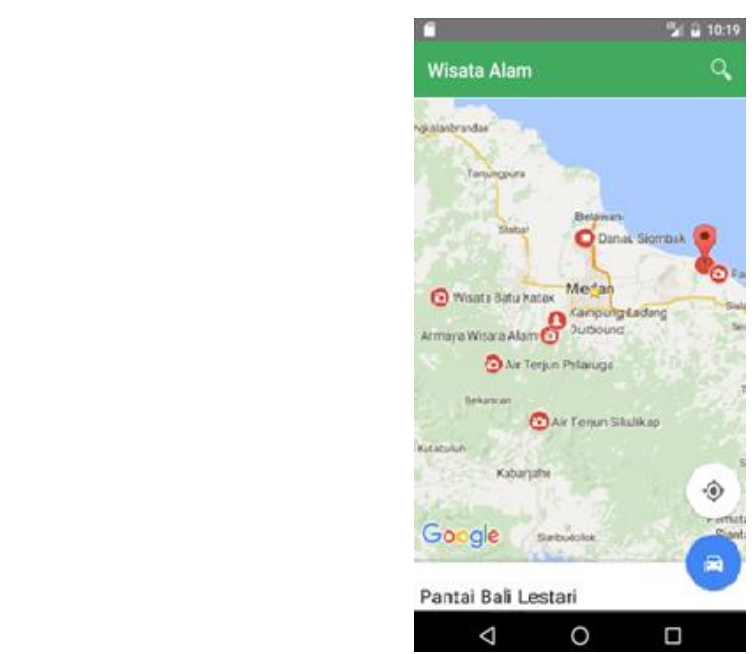

Gambar 11. Tampilan Peta Lokasi Aplikasi Wisata Alam di Android

\section{KESIMPULAN}

Berdasarkan hasil analisa yang dilakukan, perangkat lunak yang telah penulis rancang masih jauh dari sempurna. Dari keseluruhan hasil pengujian yang dilakukan dapat disimpulkan sebagai berikut :

1. Telah dihasilkan suatu perangkat lunak yang memberikan informasi objek-objek wisata yang ada di Sumatera Utara.

2. Sistem informasi geografis ini dapat membantu wisatawan yang berkunjung ke Sumatera Utara untuk mengetahui lokasi objek wisata alam yang ada di kabupaten dan kecamatan melalui mobile android.

3. Sistem informasi geografis ini dapat mempermudah user/wisatawan dalam mencari informasi obyek dan lokasi wisata alam di Sumatera Utara.

4. Sistem informasi geografis wisata alam ini berhasil berjalan di dua platform berbeda yaitu web dan Mobile android.

5. Sistem informasi objek wisata ini juga menampilkan tempat-tempat wisata alam yang sebenarnya dan sesuai dengan wisata aslinya (nyata).

\section{SARAN}

Adapaun saran-saran yang dapat diberikan pada penelitian ini adalah sebagai berikut :

1. Pada penelitian ini dapat mengembangkan metode pencarian lokasi dengan menggunakan algoritma pencarian yang lebih efektif dan efesien.

2. Pada Aplikasi Wisata Alam dapat menambahkan fitur untuk restourant, penginapan dan transport umum menuju ke lokasi wisata.

3. Sebaiknya untuk menghasilkan tampilan lebih reality dapat menerapakan model 3D pada aplikasi GIS.

4. Untuk dapat berjalan tanpa koneksi internet Sistem ini perlu dikembangkan dengan menggunakan Peta Offline.

\section{UCAPAN TERIMA KASIH}

Penulis mengucapkan terima kasih kepada DIKTI yang telah memberi dukungan financial terhadap penelitian ini. 


\section{DAFTAR PUSTAKA}

[1]. Aris Puji Widodo. (2010). Enterprise Architecture Model untuk Aplikasi Government. Jurnal Masyarakat Informatika, Volume 1, Nomor 1 Halaman 23-30.

[2]. Aziz, Muh. (2006). Sistem Informasi Geografis Bebasis Dekstop dan Web. Gava Media, Yogyakarta.

[3]. Budiyanto, Eko. (2005). Sistem Informasi Geografis Menggunakan ArcView GIS. Andi, Yogyakarta.

[4]. Charlie Collins, Michael D. Galpin, Matthias Käppler. (2012). Android in Practice. Shelter Island, New York: Manning Publications Co

[5]. Deny Wiria Nugraha.(2012). Perancangan Sistem Informasi Geografis Menggunakan Peta Digital. Jurnal Ilmiah Foristek Vol. 2, No. 1, Maret 2012

[6]. Diana Ikasari, BennyIrawan, Esti Setianingsih. (2009). Pemetaan Fasilitas Sosial dan fasilitas Umum Berbasis Sistem Informasi Geografis (Studi Kasus di DKI Jakarta). Jurnal Informatika Komputer No 1, Volme 14, April 2009

[7]. Burnette Ed. (2009). Hello, Android: Introducing Google's Mobile Development Platform. New York: The Pragmatic.

[ 8]. Ilhamdaniah, Bayu Erfianto. (2009). Pembuatan Aplikasi Webgis Pada Infrastruktur Data Spasial Daerah (IDSD) Studi Kasus: Kabupaten Majalengka. Jurnal Tekno Insentif Kopwil4, Volume 3 No.1, Juli 2009

[ 9]. Inixindo, 2011, Android Programming. Inixindo Jogja.

[ 10]. Munawar, 2005, Pemodelan Visual Dengan UML, Graha Ilmu, Yoyakarta

[11]. Prahasta Eddy, 2009, Sistem Informasi Geografis : Konsep-Konsep Dasar (Perspektif Geodesi \& Geomatika), Informatika Bandung

[12]. Shu, Hanjie,2010, City Guide over Android,TDT4520 Specialization Project, Department of Computer and Information Science, IDI, Norwegian University of Science and Technology

[13]. Wibawa, Yudharma. 2012. Sistem Informasi Geografis Penentuan Lokasi Pembangunan Lembaga Bimbingan Belajar berbasis Web dengan metode Brown Gibson (study kasus kota malang). STIKOM Surabaya.

[14]. Yudistira, Yuan. 2011. Membuat Aplikasi iPhone Android \& Blackberry Itu Gampang. Media Kita. Jakarta. 